\title{
JADARA
}

Volume 6 | Number 3

Article 5

$1-1973$

\section{Counselor Aides for Deaf Clients}

Vernon Browning

Mr. Browing is Counselor, Project for the Deaf, Dept. of Vocational Rehabilitation, Woodrow Wilson

Rehabilitation Center, Fishersville, Virginia

Follow this and additional works at: https://repository.wcsu.edu/jadara

Part of the Social and Behavioral Sciences Commons

\section{Recommended Citation}

Browning, V. (1973). Counselor Aides for Deaf Clients. JADARA, 6(3). Retrieved from

https://repository.wcsu.edu/jadara/vol6/iss3/5 


\section{COUNSELOR AIDES FOR DEAF CLIENTS}

\section{VERNON BROWNING}

Counselor aides have been mentioned a great deal in the literature of late. Emphasis has been given to utilizing these non-professionals in a role that will increase the efficiency of the State Vocational Rehabilitation Counselor (Ayers, 1969).

One of the more compelling reasons for utilization of an aide is to assist the counselor in dealing more effectively with the client as an entity of his own subculture (HEW, 1968). It is no secret that various subcultures within our society have their own language and "life-style." Often the counselor is hard pressed to relate to a particular language and life-style of a subculture since his own may be so radically different.

Many of our deaf citizens function within what is termed a subculture within our society. They share a certain degree of alientation from society as a result of their hearing impairment. The subculture role provides a sense of belonging that is not always experienced in the hearing society. There is the camaraderie of associating with another who also meets daily the trials and tribulations of functioning in a hearing world. Acceptance and congeniality are heightened by use of special techniques of communication such as sign language.

The subculture has its own particular structure primarily as a result of communication needs. Deaf people regularly visit homes of other deaf people to fraternize and pass on information that the hearing person would pick up via the telephone and casual conversation with associates. Many deaf persons attend church services that utilize interpreters. A very interesting structure within the subculture is the local deaf club that nearly every city of substantial size possesses where regularly scheduled meetings bring deaf individuals together to socialize and to resolve common problems. All of the activities are designed to bring together individuals who share common difficulties and a common language.

Mr. Browning is Counselor, Project for the Deaf, Dept. of Vocational Rehabilitation, Woodrow Wilson Rehabilitation Center, Fishersville, Virginia. 
The counselor with normal hearing, who has had little or no experience with the deaf subculture, is most certainly going to have difficulty in working with this particular population. Communication will be the first major obstacle that is met. Many deaf clients will utilize sign language as a communication technique. This requires that the counselor must either know sign language himself or use an interpreter. It often is not easy to find an interpreter in certain geographical areas. When one is found, objection is occasionally raised by the deaf person to having an interpreter, since it involves a third party in his personal affairs. Counselors, too, are reluctant to learn sign language since they often serve only a limited number of deaf clients in a general caseload of handicapped people.

Further difficulties arise when the counselor is not fully aware of the educational, social and economic problems associated with being deaf. Very often there is reduced achievement in basic education, especially in language development. Hearing most profoundly contributes to our social development. Consider not being able to hear ordinary conversation - ponder what is lost in the social sense! Economically, how can one succeed in today's technological world being unable to adequately cope educationally and socially?

Into the scene steps the counselor aide for the deaf! Ideally, here is a person who is very proficient in the communication techniques of the deaf. $\mathrm{He}$ should be a person who has had close contact with the deaf for some time. Additionally, he should have frequented the homes of the deaf often, attended church services for the deaf or perhaps visited the various social gatherings. It may even be that this individual is a son or daughter of deaf parents and knows the deaf world on a very personal basis. Even though the aide may not have advanced education nor specific rehabilitation service training, he can make a contribution at the outset due simply to the fact that he understands the deaf and can communicate with them. An example of how a counselor aide may function is indicated by the following true incident: A young deaf lady, unemployed, discouraged, and generally unhappy at home with her mother and two children walked out in total despair. Realizing that the young lady was attempting to lose herself in the crowd, her mother telephoned a counselor aide for the deaf. An immediate search began and the deaf woman was located in a cheap rooming house some miles from her home. The counselor aide met with the young lady and persuaded her to return to her home by holding out a ray of hope to her. $\mathrm{He}$ informed her that he would support her in every way possible to obtain job training and other services as needed. The young lady was given vocational training (keypunch operator) along with maintenance funds to provide for a small apartment and food. The entire rehabilitation period took ten months with the counselor aide assisting the young lady in every way possible until she graduated from the course. Upon graduation, a job position was obtained by the counselor aide. The deaf lady started at the lowest rung of Federal Civil Service employment with a GS 1 rating. She was quickly promoted and 
now earns a living wage. Her despair has turned to hope and she is quite radiant and happy with her new found opportunity to make her own way in life.

Further, an aide who is intimately known to deaf people will attract deaf clients into vocational rehabilitation services through identification. It has been observed that potential deaf clients will not ask for assistance because the vocational rehabilitation agency and the counselor represent the same negative situation as experienced previously with other agencies. The negative experience often consists of mutual frustration by both the hearing counselor and the deaf client due to communication difficulties. If the aide possesses the communication ability and is known favorably throughout the deaf society he certainly will be in a position to be identified with by the deaf client.

Not only will the deaf client receive better service from the rehabilitation agency through the counselor aide, but the needs of the deaf subculture as a whole will be known to the agency and services can be created around these needs. With the critical shortage of vocational rehabilitation counselors for the deaf who possess communication skills and knowledge of the deaf, it behooves rehabilitation agencies to give attention to rehabilitation aides for the deaf who can assist the rehabilitation counselor who handles a general caseload.

\section{REFERENCES}

Ayers, George E. (ed.) The Use of Support Personnel in Social and Rehabilitation Service Programs. Proceedings of a Regional Conference held at Kansas City, Missouri, May 1969. Washington, D.C.: HEW, 1969.

Use of Support Personnel In Vocational Rehabilitation. Rehabilitation Service Series Number 69-13. Washington, D.C.: HEW, 1968. 